\title{
PRIHODNOST ZIMSKEGA TURIZMA NA PLANINI POD GOLICO V LUČI GLOBALNEGA SEGREVANJA
}

\author{
dr. Matej Ogrin, dr. Darko Ogrin, Matic Močnik, Andraž Smolej, Rok Vengar \\ Oddelek za geografijo, Filozofska fakulteta Univerze v Ljubljani \\ Aškerčeva 2, SI-I000 Ljubljana \\ e-mail: ogrin.matej@siol.net; darko.ogrin@ff.uni-lj.si
}

Izvirni znanstveni članek

COBISS 1.01

\section{Izvleček}

Vse toplejše zime so smučišče Španov vrh nad Jesenicami pahnile v nazadovanje in zimski turizem na Planini pod Golico na rob propada. Pri morebitnem oživljanju zimskega turizma se v luči novih podnebnih razmer postavlja vprašanje smotrnosti vlaganja v klasični zimski turizem. Prispevek analizira trende temperature zraka v zimskih mesecih in trende snežne odeje na Planini pod Golico z namenom ugotoviti smiselnost razvoja zimskega turizma. V sklepnem delu so navedeni predlogi za novo, trajnostno obliko turistične ponudbe na Planini pod Golico na osnovi lokalnih potencialov.

Ključne besede: Planina pod Golico, podnebne spremembe, trajnostni turizem, smučanje

\section{THE FUTURE OF WINTER TOURISM IN PLANINA POD GOLICO IN} THE LIGHTS OF GLOBAL WARMING

\begin{abstract}
Warmer winters have brought the ski area Španov vrh near Jesenice in decline. New climate conditions put plans of conventional ski tourism in a different point of a view. The article analysis trends of air temperature and snow conditions in winter months at Planina pod Golico to find out if weather conditions assure development of classical winter tourism at ski area Španov vrh. As alternative to conventional way of tourism, the article recommends some new, more sustainable solutions for development of tourism, which could bring renaissance to Planina pod Golico.
\end{abstract}

Key words: Planina pod Golico, climate changes, sustainable tourism, skiing 


\section{UVOD}

Območje Planine pod Golico sodi v enega lepših in doživljajsko zanimivejših predelov slovenskega sredogorja, hkrati je to prostor, kjer je v preteklosti turizem že igral večjo vlogo kot jo igra danes, čeprav potencial za turistični razvoj območja danes ni nič manjši kot nekoč. Območje je v Sloveniji verjetno najbolj poznano po samoniklih narcisah (ključavnicah) ter najbolj znani polki na svetu, skladbi ansambla bratov Avsenik, ki se imenuje Na Golici. A trendi v turizmu se spreminjajo in spreminjajo se tudi naravne danosti, s čimer imamo v mislih predvsem podnebne spremembe. Te se v zadnjih desetletjih pomembno odražajo ravno v smučarskem turizmu, zlasti v nižinah in v sredogorskih območjih. To so postala zelo ranljiva območja glede zanesljivosti snežne odeje, ki je za smučanje temeljni pogoj. Hkrati so tudi večinoma minili časi množičnega, cenenega alpskega turizma.

Tudi zahteve povprečnega obiskovalca se spreminjajo in na trajnostni razvoj že dolgo prisegajo tako nekateri turistični delavci kot tudi vse številnejši obiskovalci, ki motiv za obisk nekega kraja ali območja vse pogosteje povezujejo z motivi doživljanja narave. Takim, mehkim oblikam turizma v Alpah posvečajo vse večjo pozornost, ustvarjajo pa tudi pomembno dodano vrednost na lokalni ravni, pri čemer so nosilne sposobnosti okolja bistveno manj prizadete kot pri konvencionalnih oblikah turizma (množične prireditve, veliki nastanitveni, smučarski in gostinski kompleksi, idr.).

V prispevku bomo analizirali podnebne dejavnike in trende, ki jih beležijo na Planini pod Golico v zadnjih tridesetih letih, v luči oživitve smučarskega turizma na smučišču Španov vrh, ter podali možne rešitve za ponovno oživitev turizma na Planini pod Golico. Podnebna analiza vsebuje pregled snežnih in temperaturnih razmer pozimi, s posebnim poudarkom na mesecih december, januar, februar ter marec. Raziskavo so finančno podprli Občina Jesenice, Lokalna akcijska skupina za razvoj podeželja 'Gorenjska košarica' in Evropski kmetijski sklad za podeželje, njen naročnik pa je bila Občina Jesenice.

\section{KRATKA PREDSTAVITEV OBMOČJA}

Planina pod Golico leži v severozahodni Sloveniji, na 970 m nadmorske višine na prisojnem pobočju Zahodnih Karavank v občini Jesenice, v neposredni bližini meje z Avstrijo. Vas obkrožajo vrhovi Rožca (1587 m), Velika Golica (1834 m) in Španov vrh (1334 m). Nahaja se v toplejšem pasu nad območji temperaturnega obrata zgornje Savske doline in na prisojah, zaradi česar je povprečna letna minimalna temperatura za $1,5^{\circ} \mathrm{C}$ višja kot v 100 m nižje ležečih Ratečah na dnu doline. Prav to dejstvo je pomembno pripomoglo k poselitvi tega območja.

Prvotno so območje poselili pastirji, ki so svojo živino pasli na pobočjih Golice, odtod tudi izhaja prvotno poimenovanje vasi Planina. Po odkritju bogatega nahajališča železove rude so se v 14. st. začeli priseljevati rudarji (višinska kolonizacija), ki jim je bil podeljen ortenburški rudarski red. V drugi polovici 17. st. je bila v vasi na pobudo italijanske rodbine Bucceleni zgrajena cerkev Svetega Križa. Tako je začelo nastajati vaško jedro okoli cerkve in vas se je vse do leta 1945 imenovala Sveti Križ, po letu 1945 pa je dobila današnje ime (TD Golica, 2011). 
Rudarstvo, ki je predstavljalo glavno zaposlitveno dejavnost prebivalstva, je sčasoma zamrlo, poselitev pa se je ohranila predvsem zaradi ugodnih klimatskih razmer. Današnja krajevna skupnost Planina pod Golico obsega naselja Plavški Rovt, Prihodi in Planina pod Golico, v njej pa je po podatkih statističnega urada januarja 2011 živelo 482 prebivalcev (SURS, 2011). Večina zaposlenih prebivalcev se dnevno vozi na delo na Jesenice in v Kranj. Tu ni več nobene kmetije, ki bi se ukvarjala izključno s kmetijstvom, ki predstavlja zgolj dopolnilno dejavnost. Od še obstoječih kmetij se jih pet ukvarja z ekološkim kmetovanjem.

Planina pod Golico je turistični kraj z dolgo tradicijo, ki pa danes izgublja svoj pomen. Začetki turizma segajo v čas, ko so romarji obiskovali cerkev Svetega Križa. Razvoj turizma se je nadaljeval predvsem po zaslugi planinarjenja po okoliških hribih, a je po drugi svetovni vojni popolnoma zamrlo. Oživitev turizma je prinesla razglasitev območja za gorsko zdravilišče. Turiste so privabljale narcisne poljane, sankaška proga in smučišče Španov vrh, zgrajeno leta 1964, sedežnica pa obnovljena leta 2004. Smučišče je bilo priljubljeno tako med domačini kot med obiskovalci s širšega območja Gorenjske (Torkar Tahir, 2003). Danes je smučišče le še bleda senca nekdanje podobe, saj klimatske razmere, predvsem količina snežnih padavin, debelina in trajanje snežne odeje, ne dopuščajo rentabilne smučarske sezone, spremenile so se tudi zahteve in navade smučarjev. Razlog turističnega zatona lahko iščemo tudi v zamudi pri prilagajanju novim oblikam turizma.

\section{PODNEBNE SPREMEMBE IN PERSPEKTIVE SMUČANJA NA SREDOGORSKIH SMUČIŠČIH}

Ugotavljanje ustreznosti klimatskih razmer nekega območja je nujno povezano z že prisotnim dvigom temperature in zelo verjetnim nadaljevanjem tega trenda, ki mu danes rečemo globalno segrevanje, h kateremu je po prevladujočem mnenju znanstvenikov največ prispeval človek s prekomerno porabo fosilnih goriv. Natančne ocene porasta temperature v prihodnje so negotove. Tako SRES scenarij (Special Report Emission Scenarios) napoveduje dvig globalne temperature za obdobje od 1990 do $2100 \mathrm{v}$ razponu od 1,4 do $5,8{ }^{\circ} \mathrm{C}$ (Houghton in sod., 2001; cv: Vrtačnik, 2008). Četrto poročilo Medvladnega odbora za klimatske spremembe (IPCC, Intergovernmental Panel on Climate Change) v najbolj optimističnem scenariju napoveduje dvig temperature za 1,1 do $2,9{ }^{\circ} \mathrm{C}$, kot najbolj črn scenarij pa navaja dvig temperature od 2,4 do $6,4^{\circ} \mathrm{C}$ do leta 2100 (Climate change, 2007; cv: Vrtačnik, 2008). Takšen dvig temperature se po analizah podnebja V preteklosti v zadnjih 10.000 letih še ni zgodil (Vrtačnik Garbas, 2008).

Pozimi dvig temperature ne pomeni samo hitrejšega taljenja in izginevanja snežne odeje, pač pa tudi višje temperature ob padavinskem vremenu ter s tem manj dni s sneženjem in več z dežjem. Obravnavano območje ne leži v pasu s pogostim in izrazitim temperaturnim obratom, ki bi lahko omilil višje temperature v obdobjih pretežno jasnega zimskega vremena. Ob takem vremenu se v nižjih legah, kot so kotline in doline, oblikuje jezero hladnega zraka, ki pomembno niža temperature zraka. Ta pojav je na večjih slovenskih smučiščih najbolj prisoten v Kranjski Gori, kjer so smučišča večinoma 
med 800 in $1000 \mathrm{~m}$ nad morjem, a jih osojna in dolinska lega s kratkotrajnim dnevnim Sončevim obsevanjem pogosto varuje pred toplim vremenom.

Omeniti velja še pojav znižane meje sneženja za alpske doline. Ta pojav povzroči, da je v alpskih dolinah in gorovjih, ki jih obdajajo, dni s sneženjem več, snežna odeja pa debelejša kot na enaki nadmorski višini stran od gorovij. To se zgodi zaradi prepletanja več dejavnikov. Eden je zajezitev hladnega zraka v dolinah, drugi je slabenje vetrov in s tem dotoka toplejšega zraka ob posebnih vremenskih položajih, tretji pa je okrepitev padavin nad gorskimi pregradami. To posledično zniža temperaturo ozračja in tako se pozimi meja sneženja $\mathrm{v}$ alpskih dolinah pogosto spusti vse do dna. Medtem ko lahko drugje v Sloveniji sneži šele nad okoli $1500 \mathrm{~m}$, lahko v omenjenih dolinah sneži do dna dolin, v Bohinju to pomeni celo do $500 \mathrm{~m}$ nad morjem. Pojav znižane meje sneženja se občasno pojavi tudi na območju Planine pod Golico, kar povzroči, da je tam več snega kot $v$ širši okolici na isti nadmorski višini. V Sloveniji je ta pojav najbolj pogost v zgornji Savski dolini, Bohinju in zgornjem Posočju. Vendar je ta pojav mogoč le, če je temperatura zraka ob močnejših padavinah na nadmorski višini okoli $1500 \mathrm{~m} 0{ }^{\circ} \mathrm{C}$ ali manj. Vremenski položaj s padavinskim vremenom in takimi temperaturami je pri nas razmeroma pogost. Največkrat gre ob takem vremenu za bližanje sredozemskega ciklona, ko z jugozahodnimi vetrovi nad naše kraje priteka vlažen, a toplejši zrak. Če se na $1500 \mathrm{~m}$ temperatura dvigne nad $0{ }^{\circ} \mathrm{C}$, potem tudi v alpskih dolinah ne more snežiti do dna dolin, saj dežuje že na grebenih. Dvig temperature ob takih padavinskih položajih v sredogorju le za približno stopinjo bi lahko v takih primerih pomenil lokalni dvig meje sneženja tudi za $1000 \mathrm{~m}$ in nesorazmerno veliko poslabšanje snežnih razmer.

$\mathrm{Na}$ tem mestu nas predvsem zanima, kaj napovedi o globalnem segrevanju pomenijo za smučarski turizem. V zadnjih desetletjih območje Slovenije, skladno s spremembami v širši okolici, doživlja podnebne spremembe, ki se kažejo z dvigom temperatur (Ogrin, D., 2003; Dolinar in sod., 2010; Dolinar, Vertačnik, 2010).

V Sloveniji je bila leta 2008 zaključena najobsežnejša raziskava na temo smučarskega turizma v luči klimatskih sprememb (Vrtačnik Garbas, 2008). Do te raziskave poglobljenih študij na to temo v Sloveniji ni bilo. V Evropi, zlasti pa v Alpah, je bilo v zadnjih letih opravljenih več obsežnih študij, ki vse kažejo na slabšanje snežnih razmer, zlasti na nižjih smučiščih. Abegg (1996; cv: Vrtačnik, 2008) navaja, da naj bi proti koncu devetdesetih let 20. st. v Švici za zanesljivo snežno odejo zadostovala nadmorska višina $1200 \mathrm{~m}$, ob dvigu temperature za $2{ }^{\circ} \mathrm{C}$ pa naj bi se ta meja dvignila na nadmorsko višino $1500 \mathrm{~m}$. Koch in Rudel (cv: König, 1998) navajata za Avstrijo, da bi ob dvigu temperature za $2{ }^{\circ} \mathrm{C}$ nižje ležeča smučišča Spodnje in Zgornje Avstrije ter Štajerske propadla, delovala bi le še visokogorska smučǐ̌ča v zahodni Avstriji. Globalno poročilo za sneg in led 2010 (Barry in sod., 2010) pa pravi, da se je v zadnjih 40 letih snežna odeja na severni polobli vsako desetletje stanjšala za 1,3 \%, padec pa je bil največji spomladi ter poleti. Napovedi snežne odeje do konca 21. st. kažejo kar 60-80 $\%$-no tanjšanje snežne odeje v vodnem ekvivalentu v večjem delu zmernih geografskih širin, le v kanadski Arktiki ter Sibiriji pričakujejo prirast snežne odeje.

Pri uporabi Gallowajevega snežnega modela, ki pri računanju trajanja snežne odeje upošteva podatke o povprečni dnevni temperaturi, njenem standardnem odklonu in povprečni mesečni količini padavin, je Vrtačnikova (Vrtačnik Garbas, 2008) prišla do zelo zanimivih 
rezultatov, ki avstrijske podatke za Slovenijo potrjujejo. Model ima, kot navaja avtorica, sicer nekaj pomanjkljivosti, a je zaenkrat najbolj točna ocena za slovenska smučišča.

$\mathrm{V}$ nadmorskih višinah med 1100 in $1500 \mathrm{~m}$ naj bi se ob dvigu temperature za $1{ }^{\circ} \mathrm{C}$ število dni s snežno odejo višjo od $30 \mathrm{~cm}$ znižalo za 13 do $46 \%$, ob porastu temperature za $2{ }^{\circ} \mathrm{C}$ pa od 38 do $68 \%$, ob otoplitvi za $3{ }^{\circ} \mathrm{C}$ pa kar od 59 do $83 \%$. Že scenarij ' $+2{ }^{\circ} \mathrm{C}$ ' pomeni po našem mnenju konec ekonomskih pogojev za smučarsko dejavnost na območju Planine pod Golico, ki je že sedaj v razmeroma neugodnih naravnih pogojih z zelo veliko variabilnostjo snežne odeje.

\section{METODOLOGIJA}

Pri raziskovanju podnebnih sprememb in prihodnosti zimskega turizma (s poudarkom na smučarskem turizmu) na Planini pod Golico smo na temelju zbranih in obdelanih podatkov o temperaturnih in snežnih razmerah uporabili interpretativno metodo, $\mathrm{s}$ katero smo pojasnili rezultate obdelave. Podatki so bili zbrani ob rednih dnevnih meritvah meteorološke postaje Planina pod Golico, ki leži na nadmorski višini 970 m, v obdobju 1979-2008. V analizi smo upoštevali, da se glavna smučarska sezona v Sloveniji običajno prične decembra in traja do konca marca, kar velja za sredogorska in nižje ležeča smučišča. Meteorološke podatke za potrebe analize smo pridobili iz spletnega arhiva podatkov meteoroloških postaj Agencije Republike Slovenije za okolje (ARSO).

Pri snežnih razmerah smo se osredotočili na število dni s snežno odejo ter na število dni s snežno odejo nad $30 \mathrm{~cm}$ in nad $50 \mathrm{~cm}$. Število dni s snežno odejo je osnovni pokazatelj, saj kaže na dolžino trajanja zimskih razmer v naravi. A razmere za smučanje podrobno opišejo šele podatki o številu dni s snežno odejo nad $30 \mathrm{~cm}$, saj ta debelina snežne odeje velja za tisto, ki še omogoča smučanje na smučiščih, kjer površje ni zakraselo ali skalnato. V analizo smo dodali tudi podatke o številu dni s snežno odejo nad 50 cm, saj to kaže na dolžino za smučanje zelo ugodnih snežnih razmer. Poleg celoletnih podatkov smo analizirali tudi podatke o snežnih razmerah v mesecih od decembra do marca, ko se večinoma odvija smučarska sezona. Podatke smo prikazali v obliki časovne vrste, izračunali smo tudi linearne trende za kazalce snežne odeje. Podobno smo se lotili tudi analize temperaturnih razmer. Analizirali smo podatke o povprečnih dnevnih temperaturah, prikazani so tudi podatki o povprečni maksimalni in povprečni minimalni temperaturi zraka.

\section{TRENDI SNEŽNIH IN TEMPERATURNIH RAZMER NA PLANINI POD GOLICO V OBDOBJU 1979-2008}

\section{I. Snežne razmere in linearni trendi}

Za obratovanje smučišča je nujen pogoj snežna odeja. Snežna odeja se lahko pojavi naravno ob sneženju, ali pa jo ustvarimo umetno - s snežnimi topovi, ki proizvajajo umeten ali kompakten sneg. $\mathrm{V}$ tem poglavju bomo analizirali naravne 
pogoje, ki zagotavljajo snežno odejo, oziroma trajanje in debelino naravne snežne odeje. Uporabili bomo podatke o številu dni s snežno odejo ter o številu dni s snežno odejo nad 30 in nad $50 \mathrm{~cm}$ za meteorološko postajo Planina pod Golico v obdobju od decembra do marca.

Slika 1: Število dni s snežno odejo in linearni trend na Planini pod Golico v obdobju 1979-2008

Figure 1: Number of days with snow cover and the linear trend for Planina pod Golico in the period 1979-2008

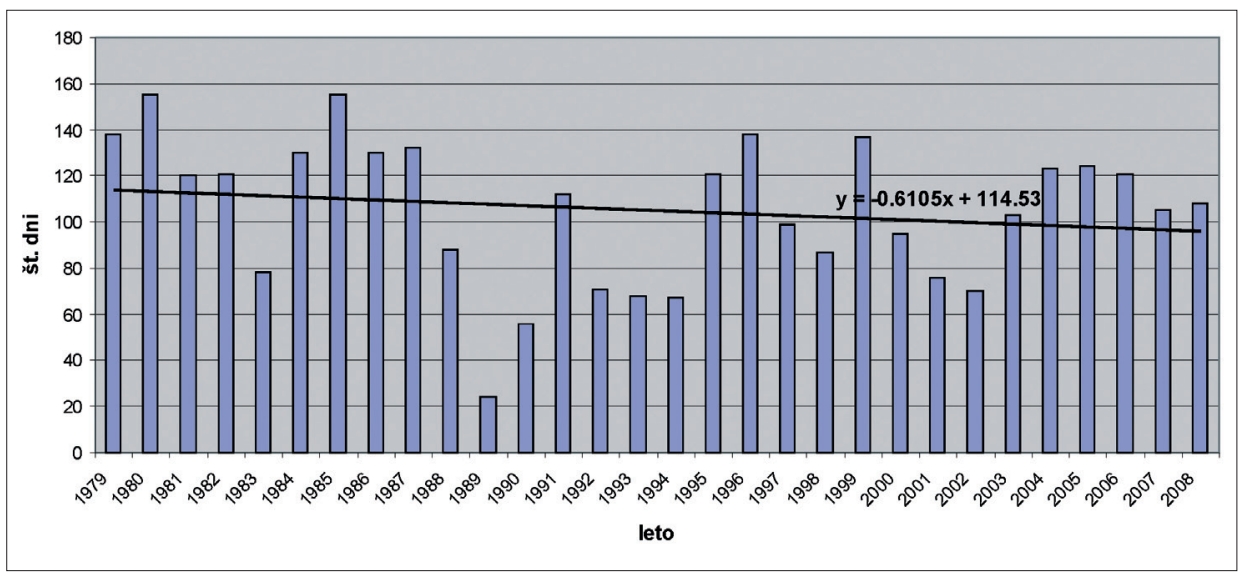

Vir/Source: arhiv ARSO

Preglednica 1: Prvi in zadnji dan s snežno odejo v obdobju 1979-2008 na Planini pod Golico Table 1: The first and last day with snow cover in the period 1979-2008 in Planina pod Golico

\begin{tabular}{|l|l|l|l|}
\hline $\begin{array}{l}\text { Povprečni prvi dan s } \\
\text { snežno odejo }\end{array}$ & Interval & $\begin{array}{l}\text { Povprečni zadnji dan s } \\
\text { snežno odejo }\end{array}$ & Interval \\
\hline 3. november & $\begin{array}{l}\text { 19. oktober }-18 . \\
\text { november }\end{array}$ & 24. april & 11. april - 7. maj \\
\hline
\end{tabular}

Vir/Source: arhiv ARSO

Povprečno število dni s snežno odejo v obdobju 1979-2008 je bilo 105, standardni odklon pa 31, kar kaže na njeno zmerno nihanje. Snežna odeja se na Planini pod Golico v povprečju prvič pojavi 3. novembra, oziroma enkrat med 19. oktobrom in 18. novembrom, zadnji dan s snežno odejo pa je 24. april, oziroma med 11. aprilom in 7. majem. Vendar snežna odeja v vmesnem času ne traja nepretrgoma, kar zlasti velja za obdobje ob začetku in koncu zime. 
Za smučarsko sezono zgodnje sneženje ne predstavlja velike prednosti, zlasti če se zgodi že oktobra. Oktobra še nobeno od slovenskih smučišč ne deluje, četudi se za nekaj dni pojavi ustrezna snežna odeja. Vreme je v tem času na splošno še pretoplo in ohladitve, ki prinesejo snežno odejo, so kratke in jim zelo pogosto sledi otoplitev z višjimi temperaturami. Te lahko na nadmorski višini okoli $1500 \mathrm{~m}$ presežejo tudi $10{ }^{\circ} \mathrm{C}$, pogosto pa tudi dežuje, kar za svežo snežno odejo pomeni hitro taljenje in izginevanje. Tudi novembra ni navada, da bi naprave obratovale, razen v drugi polovici meseca in še to razmeroma redko na višjih smučiščih, kot so Rogla, Krvavec, Vogel in Kanin, saj je snežna odeja še vedno bodisi kratkotrajna ali pretanka.

Upoštevati moramo tudi navade ljudi ter razpoložljivi čas. V tem delu leta ni počitnic ali daljših praznikov, ki bi omogočali smučanje. Dejansko pride v poštev obdobje s snežno odejo od decembra do marca, lahko tudi še v prvi polovici aprila. A v aprilu mnogi ljudje raje izkoristijo prosti čas drugače kot s smučanjem, če pa že gredo smučat, raje izberejo višja smučišča, kjer so razmere ugodnejše. Spomladi je namreč lahko kljub razmeroma dobrim snežnim razmeram smučanje manj prijetno, če so temperature previsoke in se snežna odeja zmehča. Zato pridejo v poštev zgodnje dopoldanske ure ter višja in osojna smučišča. Smučišče Španov vrh ni pretirano visoko, res pa je, da je obrnjeno proti zahodu, tako da ima manjše dopoldansko segrevanje ter počasnejše mehčanje in taljenje snežne odeje v spomladanskih dopoldnevih.

Trend spreminjanja števila dni s snežno odejo je padajoč, povprečno število dni s snežno odejo na Planini pod Golico se je v obdobju 1979-2008 zmanjšalo za 18 dni. V desetletju 1979-1988 je bilo takih dni kar 135, v desetletju 1988-1998 le 84 in v desetletju 1999-2008 106. Snežna odeja se je pojavila vsako leto, najmanj dni s snežno odejo (24) je bilo leta 1989, največ leta 1985, ko je snežna odeja ležala 155 dni oziroma dobrih 5 mesecev. Nihanje števila dni s snežno odejo je zmerno, saj znaša standardni odklon v celotnem obdobju 31, v posameznih desetletjih pa po vrsti 25 , 34 in 21 dni. Vendar samo pojav snežne odeje ni dovolj za smučanje. Kot osnovni pogoj, da je smučanje sploh mogoče, smo določili mejno višino snežne odeje $30 \mathrm{~cm}$. Ker kamninska podlaga smučišča Španov vrh in okolice v glavnem ni kraška in ni zelo skalnata, pač pa je smučišče poraslo s travo in ga, razen v zgornjem delu, pokriva razmeroma debela prst, ocenjujemo, da je $30 \mathrm{~cm}$ debela snežna odeja zadosten minimum za obratovanje smučišča. 
Slika 2: Število dni s snežno odejo nad 30 cm na Planini pod Golico v obdobju 1979-2008 Figure 2: Number of days with snow cover exceeding $30 \mathrm{~cm}$ in Planina pod Golico during the period 1979-2008

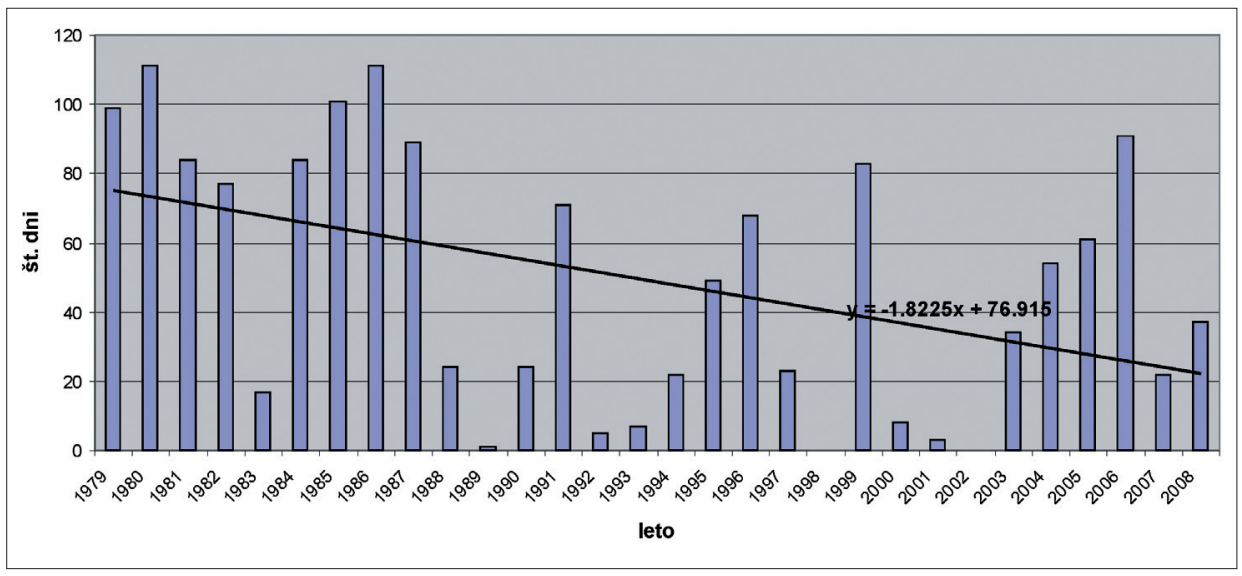

Vir/Source: arhiv ARSO

Slika 2 nam kaže precej slabšo sliko trenda snežnih razmer za Planino pod Golico kot ga prikazuje slika 1. Linearni trend pokaže, da se je povprečno število dni z več kot $30 \mathrm{~cm}$ debelo snežno odejo v obdobju 1979-2008 močno zmanjšalo, in sicer s 77 na samo 22, torej za 55 dni. Standardni odklon celotnega obdobja znaša kar 38 dni, v posameznih desetletjih pa niha od 27 do 33 dni. Razen v prvi dekadi, so se v zadnjih dveh pojavile tudi zime brez snežne odeje višje od $30 \mathrm{~cm}$, torej pogojev za smučanje sploh ni bilo. V celotnem obdobju znaša letno povprečje 49 dni s snežno odejo nad 30 cm debeline, a so zelo velike razlike po posameznih desetletjih, kar je posledica velikega nihanja snežne odeje. Ne smemo zanemariti niti vpliva globalnega segrevanja ozračja, kar se kaže tudi na lokalnem nivoju Planine pod Golico v vse višjih temperaturah zraka. V desetletju 1979-1988 je bilo tako v povprečju 80 dni s snežno odejo nad $30 \mathrm{~cm}$, v obdobju 1989-1998 samo 27 in v obdobju 1999-2008 39 dni. Potrebno se je zavedati, da je alpsko smučanje in s tem obratovanje žičnice gospodarska dejavnost. Če je odvisna samo od naravnega snega, potem mora biti obdobje z ustrezno debelino snežne odeje dovolj dolgo in zanesljivo.

»O zanesljivi naravni zasneženosti govorimo, ko je v obdobju desetih let vsaj sedem zim z vsaj 100 dni trajajočo snežno odejo, ki je primerna za smučanje. Običajno je za smuko potrebnih vsaj $30 \mathrm{~cm}$ snega, na visokogorskih območjih, kjer je površje bolj kamnito, pa tudi $1 \mathrm{~m}$ in več. Ker ima smučarski turizem v Sloveniji bolj miniaturno obliko, pravilo 100 dni velja le za največja smučišča, medtem ko so na mnogih manjših smučiščih zadovoljni že s 60 dnevi smuke.« (Vrtačnik, 2008, str. 10). Če bi iz omenjenega pravila sklepali na ugodnost snežnih razmer za rentabilno smuko na Planini pod Golico, vidimo, da so tam pogoji izrazito neugodni. V obdobju 1979-1988 so bile 
take zime samo tri, v naslednjih dvajsetih letih pa nobene več. Če omilimo to pravilo na 60 dni, je bilo v obdobju 1979-1988 takih zim osem, v desetletju 1989-1998 dve, v desetletju 1999-2008 pa tri. Tudi pri omiljenem kriteriju so naravne snežne razmere nezadostne.

Slika 3: Število dni s snežno odejo nad 50 cm na Planini pod Golico v obdobju 1979-2008 Figure 3: Number of days with snow cover exceeding $50 \mathrm{~cm}$ in Planina pod Golico during the period 1979-2008

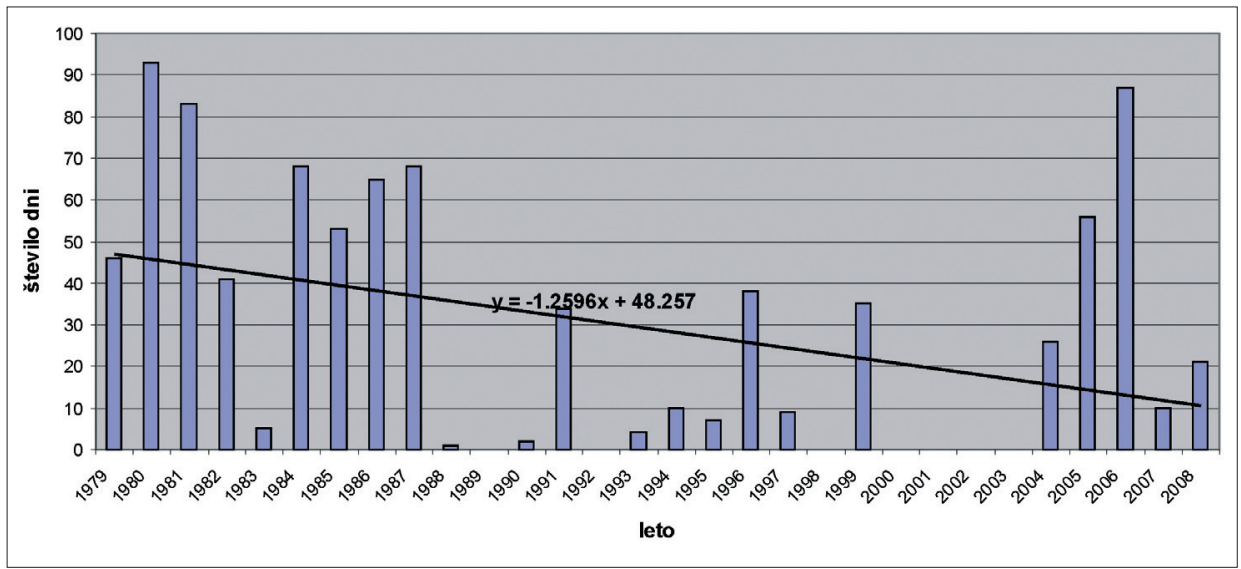

Vir/Source: arhiv ARSO

Če je meja $30 \mathrm{~cm}$ naravnega snega minimum za ugodno smuko, predstavlja $50 \mathrm{~cm}$ debela snežna odeja mejo zelo ugodnih snežnih razmer. V zasneženi pokrajini nudi smučanje povsem drugačen občutek, drugačno doživljanje te dejavnosti in pokrajine, kot če je snega v okolici malo ali celo nič. Poleg tega je debela snežna odeja zagotovilo dolge smučarske sezone. Ta kazalec ima dopolnilen značaj, vseeno pa kaže zanimiv potek snežnih razmer.

Povprečno število dni s snežno odejo nad $50 \mathrm{~cm}$ je bilo v Planini pod Golico v obravnavanem 30-letnem obdobju 29 dni, standardni odklon pa kar 30 dni, kar pomeni, da je nihanje zelo veliko, snežne razmere negotove, pojavljajo se tudi zime brez snežne odeje, ki bi bila debelejša od $50 \mathrm{~cm}$. V desetletju 1979-1988 takih zim še ni bilo, zato pa so v obdobju 1989-1998 bile že tri take zime, v obdobju 1999-2008 pa celo štiri, kar je skoraj polovica vseh zim.

Natančnejši pogled po desetletjih nam pokaže tudi trend hitrega zmanjševanja takih dni. Povprečno število dni s snežno odejo nad $50 \mathrm{~cm}$ je bilo v desetletju 1979-1988 kar 53, v naslednjem desetletju le 10 in v obdobju 1999-2008 24. Tudi pri tem kazalcu je nihanje zelo veliko, saj standardni odklon v zadnjih dveh desetletjih celo presega povprečno vrednost. Iz slike 3 lahko razberemo, da se je v obdobju 1979-2008 povprečno število dni s snežno odejo nad $50 \mathrm{~cm}$ zmanjšalo za 38 dni. 
Preglednica 2: Povprečno število dni s snežno odejo v smučarski sezoni, število dni s snežno odejo, debelejšo od $30 \mathrm{~cm}$, in trend števila dni s snežno odejo, višjo od $30 \mathrm{~cm}$, na Planini pod Golico v obdobju 1979-2008

Table 2: Average number of days with snow cover in ski season, the number of days with snow cover exceeding $30 \mathrm{~cm}$, and the trend in the number of days with snow cover exceeding $30 \mathrm{~cm}$ in Planina pod Golico during the period 1979-2008

\begin{tabular}{|l|c|c|c|c|}
\hline & December & Januar & Februar & Marec \\
\hline Število dni s snežno odejo & 20 & 23 & 22 & 19 \\
\hline Trend števila dni s snežno odejo & 3 & -1 & -3 & -8 \\
\hline Število dni s snežno odejo nad 30 cm & 6 & 12 & 12 & 13 \\
\hline $\begin{array}{l}\text { Linearni trend števila dni s snežno odejo nad } \\
30 \mathrm{~cm} \text { (dni na 30 let) }\end{array}$ & -1 & -18 & -18 & -10 \\
\hline
\end{tabular}

\section{Vir/Source: Arhiv ARSO}

Linearni trend spreminjanja števila dni s snežno odejo je v celotnem obdobju razmeroma majhen, le v marcu je zmeren. Tedaj znaša zmanjšanje 8 dni na 30 let. V mesecu decembru je trend celo pozitiven in kaže na rahel porast takih dni. Trend zmanjšanja števila dni s snežno odejo, debelejšo od $30 \mathrm{~cm}$, je zelo izrazit in za obravnavano 30-letno obdobje znaša januarja in februarja 18 dni, marca pa 10 dni (preglednica 2). Le v decembru ni bistvenih razlik, a ta mesec ima v povprečju le šest takih dni in za smučarsko sezono ne pomeni veliko.

S stališča naravne oskrbe smučišča s snežno odejo so podatki o zmanjšanju števila dni s snežno odejo nad $30 \mathrm{~cm}$ zaskrbljujoči in potrjujejo tezo o tanjšanju snežne odeje, kar predstavlja dražje pogoje poslovanja in zahteva visoka vlaganja v umetno zasneževanje, če želimo zagotoviti nemoteno obratovanje smučišča. Večja vlaganja pa morajo zagotoviti tudi gotove in dovolj visoke prihodke, zato se pogosto postavi vprašanje, ali je (gledano samo s stališča ekonomske upravičenosti) taka investicija sploh vzdržna in ekonomsko trajnostna. 
Slika 4: Debela snežna odeja na Planini pod Golico je vse manj pogosta (foto: M. Branc) Figure 4: Heavy snow in Planina pod Golico is becoming less frequent (photo: M. Branc)

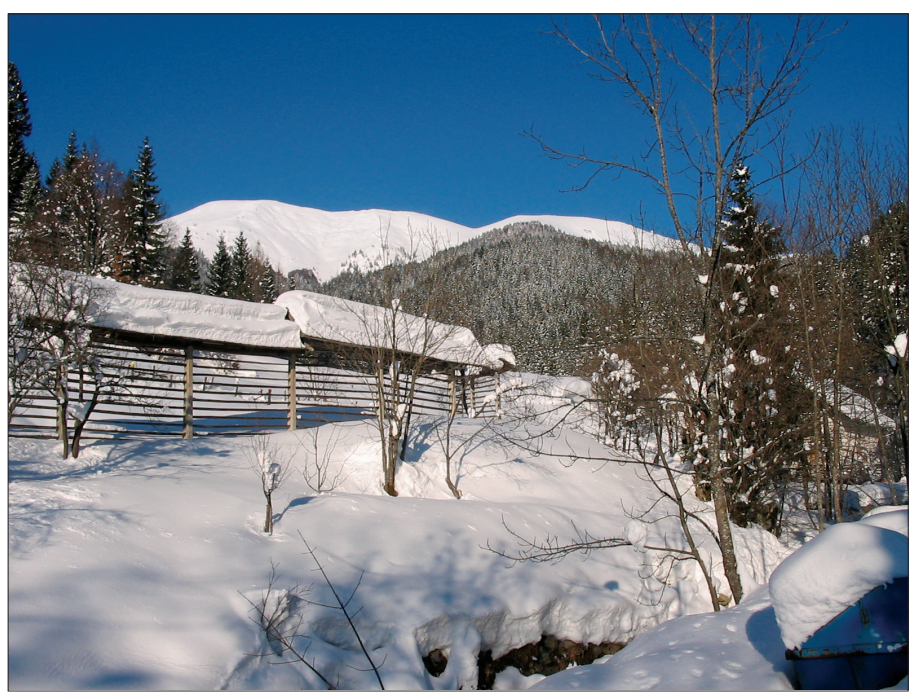

\subsection{Temperaturne razmere}

Kot dejavnik, ki vpliva tako na pojav sneženja kot tudi na trajanje snežne odeje, smo analizirali tudi temperaturne razmere $\mathrm{v}$ mesecih od decembra do marca in jih predstavili tako po dekadah, kot tudi enotno v časovni vrsti.

Preglednica 3: Povprečna temperatura zraka $\left(v^{\circ} \mathrm{C}\right)$ v štirimesečnem obdobju (decembermarec) po dekadah v obdobju 1979-2008 na Planini pod Golico

Table 3: Average air temperature $\left({ }^{\circ} \mathrm{C}\right)$ in a four-month period (December-March) by decades during the period 1979-2008 in Planina pod Golico

\begin{tabular}{|l|c|c|c|c|}
\hline & $1979-1988$ & $1989-1998$ & $1999-2008$ & $1979-2008$ \\
\hline Povprečna temperatura & $-1,6$ & $-0,1$ & $-0,4$ & $-0,7$ \\
\hline
\end{tabular}

Vir/Source: arhiv ARSO 
Preglednica 4: Linearni trendi $\left({ }^{\circ} \mathrm{C} v 30\right.$ letih) povprečne dnevne, povprečne maksimalne dnevne in povprečne minimalne dnevne temperature v obdobju 1979-2008 na Planini pod Golico

Table 4: Linear trends $\left({ }^{\circ} \mathrm{C}\right.$ in 30 years) of the average daily, average maximum daily and average daily minimum temperature during the period 1979-2008 in Planina pod Golico

\begin{tabular}{|l|c|c|c|c|}
\hline & December & Januar & Februar & Marec \\
\hline Povprečna dnevna temperatura $\left({ }^{\circ} \mathrm{C}\right)$ & $-0,3$ & 2,7 & 2,4 & 0,9 \\
\hline Povprečna maksimalna dnevna temperatura $\left({ }^{\circ} \mathrm{C}\right)$ & 0 & 3,1 & 3,5 & 2,5 \\
\hline Povprečna minimalna dnevna temperatura $\left({ }^{\circ} \mathrm{C}\right)$ & 0,5 & 4 & 3,2 & 0,9 \\
\hline
\end{tabular}

Vir/Source: arhiv ARSO

Kljub temu da so decembrske temperature na Planini pod Golico pokazale rahel negativni trend, so ostali trije meseci v 30-letnem obdobju pokazali občuten porast povprečne temperature zraka. Razen $\mathrm{v}$ marcu so povprečne mesečne temperature $\mathrm{V}$ ostalih mesecih v sezoni sicer negativne, a trend je za razvoj smučarskega turizma zaskrbljujoč. Trendi kažejo na naraščanje temperatur, višje temperature pa pomenijo več taljenja snega, več dežja, manj ugodne pogoje za nastanek naravne snežne odeje in manj možnosti za uspešno umetno zasneževanje, če bi do zgraditve takšnega sistema prišlo. Višje temperature pomenijo tudi več stroškov za vzdrževanje smučišča (več umetnega zasneževanja, dražje organizacije smučarskih tekem) in hitrejši

Slika 5: Potek in linearni trend povprečne temperature zraka štirimesečnega obdobja od decembra do marca na Planini pod Golico v obdobju 1979-2008

Figure 5: Flow and linear trend of the average air temperature from December to March in Planina pod Golico during the period 1979-2008

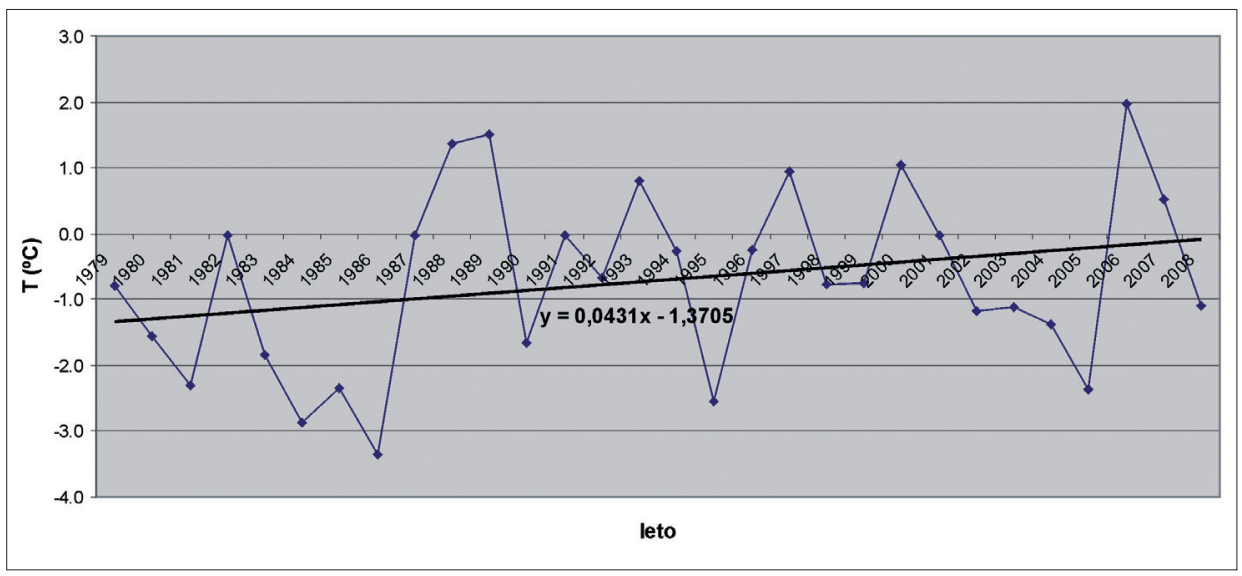

Vir/Source: arhiv ARSO 
konec smučarske sezone. Na podlagi 30-letnega niza lahko rečemo, da se napovedi segrevanja ozračja uresničujejo, skupni trend v mesecih december, januar, februar in marec je $1,3{ }^{\circ} \mathrm{C}$ na 30 let, kar je celo več od projekcij najpogostejših scenarijev globalnega segrevanja ozračja. Trend med meseci se pomembno razlikuje: decembra je v celotnem obdobju prisoten celo rahel trend zniževanja povprečne temperature $\left(-0,3{ }^{\circ} \mathrm{C}\right.$ na 30 let), januarja znaša $+2,7^{\circ} \mathrm{C}$, februarja $+2,4{ }^{\circ} \mathrm{C}$ in marca $+0,9{ }^{\circ} \mathrm{C}$ na 30 let (preglednica 4).

\section{SKLEP IN PREDLOGI ZA BODOČI RAZVOJ TURIZMA NA PLANINI POD GOLICO}

Poteka temperatur $\mathrm{v}$ prihodnje ne moremo napovedati $\mathrm{s}$ preprosto ekstrapolacijo trendov preteklosti $\mathrm{v}$ prihodnost. Glede na napovedane trende segrevanja so trendi na Planini pod Golico previsoki in povsem mogoče je, da se bodo pojavila tudi krajša obdobja, ko se bodo temperature celo nekoliko znižale, se ustalile ali se zviševale počasneje. A ob upoštevanju predpostavk večine klimatoloških napovedi in ob dejstvu, da se pred desetletji napovedani trendi bolj ali manj uresničujejo, trajne umiritve zviševanja ali celo zniževanja temperature zraka ne moremo napovedati, saj zato nimamo nobenega povoda. Nasprotno pa obstajajo razlogi, da utemeljeno pričakujemo nadaljnji porast temperature zraka in še nadaljnje slabšanje pogojev za smučarski turizem v slovenskem sredogorju, kamor Planina pod Golico in smučišče Španov vrh sodita. Že nadaljevanje sedanjih podnebnih razmer v sredogorju pod $1500 \mathrm{~m}$ n.v. predstavlja zelo negotove razmere za širitev smučarske dejavnosti.

Analiza snežnih razmer je pokazala, da je spremenljivost, predvsem pa nezanesljivost dovolj debele snežne odeje, zelo velika, 30-letni trend upadanja števila dni s snežno odejo, debelejšo od $30 \mathrm{~cm}$, pa tudi zelo izrazit. Največje zmanjšanje števila dni s snežno odejo nad $30 \mathrm{~cm}$ debeline je ravno v januarju in februarju, ko je smučarska sezona na vrhuncu, najmanjše pa v decembru, ko pogoji za smučanje na Planini pod Golico in v okolici praviloma še niso optimalni. Zmanjšanje števila dni s snežno odejo je največje marca, ko se zima poslavlja.

Število dni s snežno odejo se zmanjšuje precej počasneje kot število dni s snežno odejo, debelejšo od $30 \mathrm{~cm}$. To ni presenetljivo, saj so zime vse toplejše in manj snežene, kar pomeni slabše pogoje za nastanek in obstoj debelejše snežne odeje. Tanka snežna odeja pa ni nikakršno zagotovilo za smučanje na naravnem snegu.

Kakšne snežne razmere lahko na obravnavanem območju pričakujemo v prihodnje? Zagotovo se bo ohranila dosedanja velika spremenljivost med leti. Zelo verjetno je, da se bo v skladu s trendom porasta temperature število dni s snežno odejo dolgoročno še naprej zniževalo. To ne pomeni, da bo vsako leto ali vsako naslednje petletno obdobje manj zimsko. Povsem mogoča so tudi krajša obdobja nekoliko bolj sneženih zim, saj je podnebje precej kompleksen sistem, na katerega vpliva zelo veliko med seboj povezanih dejavnikov. Iz analize 30-letnega niza podatkov za obdobje 1979-2008 lahko zaključimo, da so trendi snežne odeje na Planini pod Golico za razvoj smučarskega turizma zelo neugodni. 
Slika 6: Tradicionalna gradnja v Javorniškem Rovtu (foto: M. Ogrin)

Figure 6: Traditional house in Javorniški Rovt (photo: M. Ogrin)

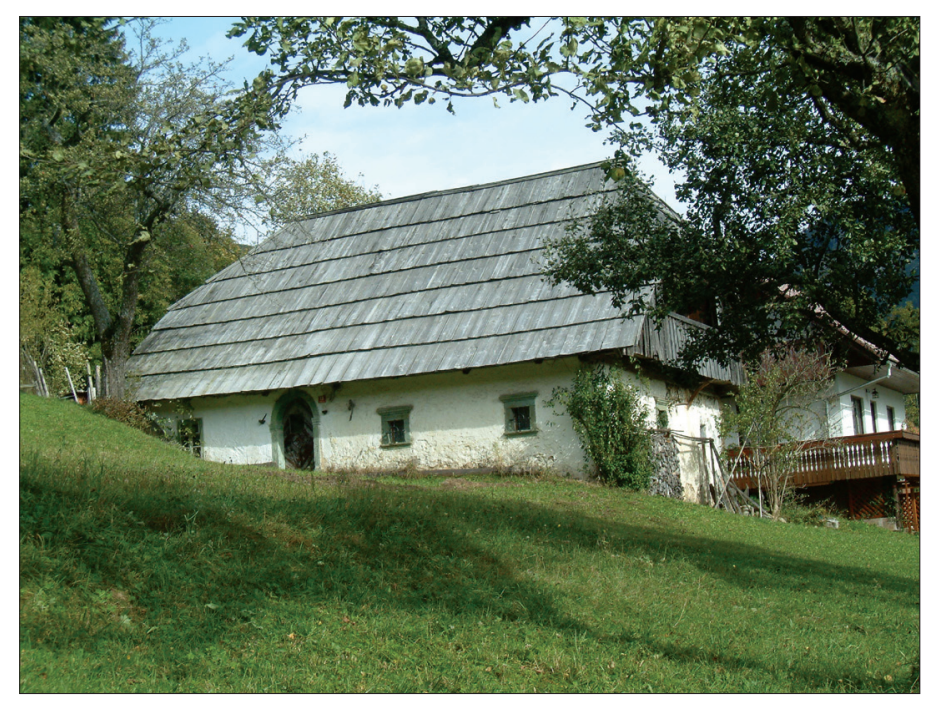

V nadaljevanju navajamo nekaj predlogov za morebiten razvoj turizma na območju Planine pod Golico. Izhajamo iz dejstev, da je raznovrstni turizem tu že obstajal in da V prihodnosti ne moremo računati na snežne razmere, ki bi zagotavljale brezskrbni zimski turizem. Tudi trendi smučarskega turizma se spreminjajo in majhnim smučiščem, brez dodatne ponudbe, nikakor ne obljubljajo preživetja.

Ker se v bližnji in malo manj bližnji okolici nahajajo pomembna turistična središča, kot so Kranjska Gora z okolico, Bled in Bohinj, Trbiž/Tarvisio v Italiji ter območje jezer in smučišč na avstrijskem Koroškem, je potrebno to upoštevati pri načrtovanju razvoja turizma $\mathrm{v}$ prihodnje. Menimo, da je potencial obravnavanega območja v inovativnem trajnostnem turizmu, ki v Sloveniji še ni zaživel tako kot v nekaterih alpskih državah. V Alpah je vse več primerov, ko so predvsem manjša turistična območja poiskala nišo v novih pristopih.

Območje Planine pod Golico je zaključeno območje s celovito pokrajinsko podobo in je iz preteklosti uspelo ohraniti nekaj prepoznavnosti. Predlagamo razvoj turizma, ki bi temeljil na interpretaciji naravne in kulturne dediščine, kar pa samo po sebi še zdaleč ni dovolj. Dodana vrednost turizma bi se lahko odražala v uresničevanju trajnostnega turizma z določenimi nosilnimi sposobnostmi. Planina pod Golico bi lahko postala prvo nizkoenergijsko naselje v Sloveniji, srednjeročno morda celo ogljično nevtralno območje. Turistom bi lahko kot prvi v Sloveniji ponudili resnični paket ekoturizma, ki bi temeljil na lokalni pridelavi in delovni sili.

Ta koncept zajema:

- Gradnjo nizkoenergijskih nastanitvenih objektov ali prenovo starih, ki so namenjeni prebivalcem in gostom. Sem sodi ogrevanje na biomaso, ki je lokalnega izvora, kar poveča dodano vrednost na lokalni ravni. Toplotno varčne stavbe, lahko tudi 
po standardu pasivne hiše, bi obiskovalcem omogočile preizkusiti način življenja v okolju prijaznih stavbah, ki pri ogrevanju ne uporabljajo fosilnih goriv. Ker so zaloge lesa na ožjem in širšem območju velike, dostop do tega vira ni problematičen. Lokalni viri lesa lahko služijo tudi kot gradbena surovina za nizkoenergijsko gradnjo.

- Planinski dom na Planini pod Golico bi lahko po zgledu nemških ali avstrijskih koč postal prva ekološka koča v Sloveniji z uveljavljenimi in priznanimi certifikati. Med opremo in ponudbo koče sodi ravnanje z odplakami in odpadki, rastlinska čistilna naprava, pridobivanje električne energije s sončnimi celicami, ogrevanje na biomaso, ekološko upravljanje koče (čim manj živil s potratno embalažo v sklopu gostinske ponudbe, pranje z ekološkimi čistili, idr.). Menimo, da bi bila že sama oblika tovrstne infrastrukture pomemben vzgib za številne obiskovalce, saj bi bila v Sloveniji prva. Javno razsvetljavo bi v vasi napravili na osnovi sončne energije, morda bi na prisojnih pobočjih lahko postavili tudi sončno elektrarno.

- Oskrba gostov z živili bi v največji možni meri temeljila na lokalnih pridelkih in ti bi morali biti v čim večji meri ekološko pridelani. To se ne more zgoditi čez noč, če lokalni prostor nima že razvitega ekološkega kmetijstva. A postopno bi se v lokalni skupnosti oblikovalo povpraševanje po ekološko pridelanih lokalnih proizvodih (meso, mleko, mlečni izdelki, sadje, zelenjava, sokovi), kar bi pomembno povečalo dodano vrednost turistične ponudbe območja.

- Ponudba storitev bi bila usmerjena v raznolike in okolju prijazne dejavnosti, kar pomeni, da bi pri vsaki od dejavnosti še posebno skrb namenjali varovanju okolja in tako svoje poslanstvo iz infrastrukturnega dela prenesli na turistično ponudbo. To npr. pomeni, da bi smučanje ostalo, a v okviru Španovega vrha in brez večjih investicij ter brez umetnega zasneževanja in dodajanja kemičnih snovi za utrjevanje snega. Vse dejavnosti, kot npr. kolesarjenje, pohodništvo, izletništvo in tek na smučeh, bi upoštevale nosilne sposobnosti okolja, obiskovalcem pa bi vsebino in upravljanje celotnega območja predstavili v obliki tematskih zloženk, morda tudi informacijskih tabel in drugih obeležij $\mathrm{v}$ pokrajini.

- Zelo pomemben vidik je mobilnost na turističnih območjih. Ta je pogosto črna ovca prizadevanj po trajnostnem turizmu. V Alpah je vse več turističnih krajev, ki si prizadevajo promet na turističnih območjih omejiti in z njim upravljati bolj trajnostno, ne da bi pri tem upadel turistični obisk. Praksa sosednjih držav kaže, da je to mogoče (Werfenweng, Chamois, Zermatt). Planina pod Golico ima za trajnostni prometni koncept za slovenske razmere skoraj idealno lego. V vas vodi iz Jesenic le ena cesta, na Jesenicah pa je pomembno avtobusno in železniško vozlišče, kamor pripelje tudi avtocesta A2 ter državna cesta, ki vodi mimo Kranjske Gore v Posočje, v Kanalsko dolino in na avstrijsko Koroško. Hkrati prostor za prostočasne dejavnosti na Planini pod Golico ni zelo obsežen in lahko zanimive točke večinoma dosežemo z nemotoriziranim prometom.

- Vsem obiskovalcem območja bi lahko ponudili ekološke počitnice, ki bi vključevale tudi prihod z javnim prevozom. Takim gostom bi bile storitve dosegljive po nekoliko nižji ceni ali pa bi za isto ceno dobili več. Gostje, ki bi se na to območje pripeljali z osebnim vozilom in bi za čas bivanja vozilo pustili na parkirišču ter se med bivanjem 
z njim ne bi vozili, bi tudi bili deležni te ugodnosti. Seveda pa je potrebno zagotoviti alternativna sredstva mobilnosti, kot so voz, sani ali smuči pozimi, vozila na bioplin ali električni pogon ter javni promet do Jesenic in navezavo naprej do Kranjske Gore in drugih turističnih krajev. Tak koncept uspešno uveljavljajo v avstrijski vas Werfenweng, pri nas pa bi ga lahko za lokalne razmere ustrezno prilagodili.

- Predlagamo postopno vzpostavitev turističnih zmogljivosti ob upoštevanju lokalnih zmogljivosti prostora (ekonomskih, socialnih in okoljskih). Smiselno je v čim večji meri v celoten turistični razvoj vpeti domačine ali ljudi iz bližnjih naselij, ki imajo pozitivno identifikacijo s krajem, torej jim pomeni nekaj več, a imajo hkrati tudi zadovoljivo mero znanja. Rast naj bo postopna, vključuje naj čim več lokalnega kapitala, tudi za ceno počasnejše rasti, saj je glavni cilj dolgoročno uspešno delovanje trajnostne turistične ponudbe, ki temelji na endogenih virih.

- Tovrstne storitve bi lahko sprva ponudili manjšim skupinam v obliki ekoloških taborov, mladinskih kolonij, morda poletnih šol trajnostnega razvoja, postopno pa tudi širši javnosti, ki želi nekaj dni preživeti na turističnem območju, katerega vplivi na okolje so zelo majhni. Srednjeročno lahko postane cilj razvoja celo prvo ogljično nevtralno naselje v Sloveniji.

Ker je območje majhno in bi temeljilo na postopnem razvoju, danes pa resnih turističnih objektov praktično nima, množičnega obiska ne more prenesti, niti mu množični turizem dolgoročno ne more prinesti želenega uspeha. Zato si lahko postavi v

Slika 7: Vasica Chamois v dolini Aoste na severozahodu Italije je vasica brez avtomobila in članica mreže Biseri Alp (foto: M. Ogrin)

Figure 7: The small village of Chamois in the Valle d'Aosta in northwestern Italy; the village is car-free and member of the Alpine Pearls network (photo: M. Ogrin)

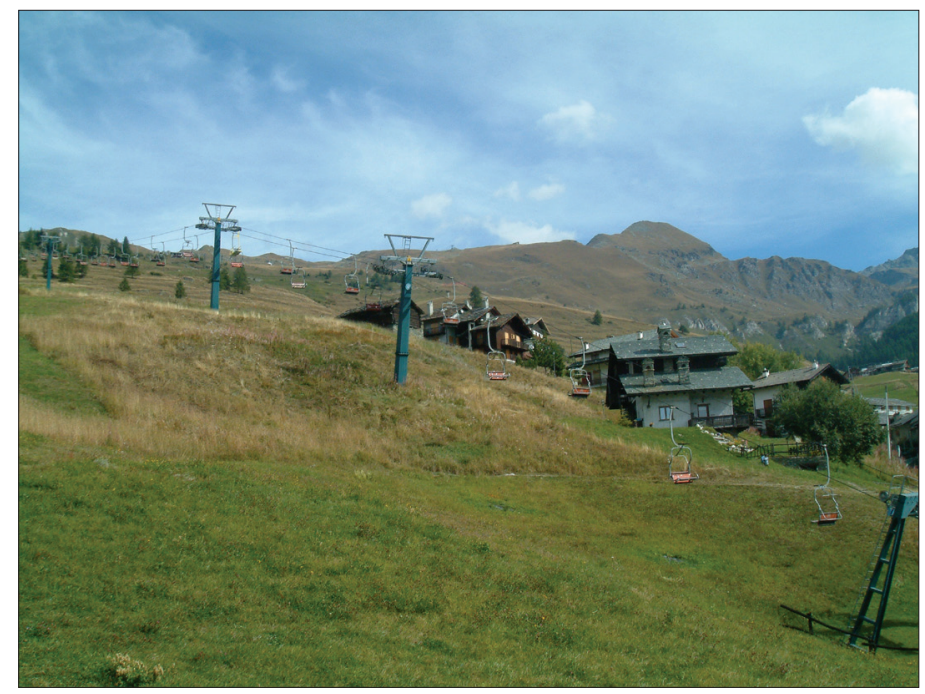


koncept turističnega delovanja maksimalno nosilnost prostora, zaradi katere je potrebno postaviti zgornjo mejo obiskovalcev. Upravljalec območja bi se povezal s turističnimi območji ter z združenji v Alpah in drugje, ki že uveljavljajo podobne koncepte turizma, ali pa so jim naklonjeni. Taki združenji sta npr. Omrežje občin - Povezanost $\mathrm{v}$ Alpah (Alliance in the Alps) in Biseri Alp (Alpine Pearls), območja oziroma občine pa so npr. Mäder (Avstrija), Werfenweng (Avstrija), Chamois (Italija), Zermatt (Švica), Budoia (Italija) in druge.

\section{Viri in literatura}

Abegg, B., 1996. Klimaänderung und Tourismus. Klimafolgenforschung am Beispiel des Wintertourismus in den Schweizer Alpen. Zürich, Vdf Hochschulverlag, 240 str. Arhiv ARSO. Klimatski podatki za Planino pod Golico v obdobju 1979-2008.

Barry, R. G., Armstrong, R., Callaghan, T., Cherry, J., Gearheard, S., Nolin, A., Russell, D., Zöckler, C., 2007. Global overview for ice \& snow. New York, United Nations Environmental Programme, 238 str.

Climate Change 2007: The physical science basis. Contribution of Working Group 1 to the Fourth assessment report of the Intergovernmental Panel on Climate Change. 2007. URL: http://www.ipcc.ch/publications_and_data/publications_ipcc_fourth_assessment_report_wg1_report_the_physical_science_basis.htm (C̈itirano 10. 11. 2011).

Dolinar, M., Nadbath, M., Vičar, Z., Vertačnik, G., Pavčič, B., 2010. Spremljanje podnebja v Sloveniji. V: Okolje se spreminja. Podnebna spremenljivost Slovenije in njen vpliv na vodno okolje. Ljubljana, ARSO, str.16-36.

Dolinar, M., Vertačnik, G., 2010: Spremenljivost temperaturnih in padavinskih razmer v Sloveniji. V: Okolje se spreminja. Podnebna spremenljivost Slovenije in njen vpliv na vodno okolje. Ljubljana, ARSO, str. 37-40.

Houghton, J. T., Ding, Y., Griggs, D. J., Noguer, M., van der Linden, P. J., Dai, X., Maskell, K., Johnson, C. A., 2001. Climate change 2001: The Scientific basis. Cambridge, Cambridge University Press, 752 str.

König, U., 1998. Tourism in a warmer world. Implications of climate change due to enhanced greenhouse effect for the ski industry in the Australian Alps. Wirtschaftsgeographie und Raumplanung, 28, 229 str. Zürich.

Ogrin, D., 2003. Spreminjanje temperature zraka in padavin po letnih časih v Ljubljani in Trstu v obdobju 1851-2002. Dela, 20, str. 115-131. Ljubljana.

SURS, 2011 (Statistični urad Republike Slovenije). URL: http://pxweb.stat.si/pxweb/Dialog/Saveshow.asp (Citirano 10. 11. 2011).

Torkar Tahir, Z., 2003. Planina pod Golico skozi čas. Jesenice, Zgornjesavski muzej, 23 str.

Turistično društvo Golica. URL: http://www.tdgolica.com (Citirano 10. 11. 2011).

Vrtačnik, K., 2008. Bomo v prihodnosti namesto v smuki uživali v nabiranju regrata? Gea, 18, str. 8-11. Ljubljana.

Vrtačnik Garbas, K., 2008. Posledice klimatske spremenljivosti v središčih zimsko-športne rekreacije v Sloveniji. Doktorsko delo. Ljubljana, Filozofska fakulteta, Oddelek za geografijo, 480 str. 


\section{THE FUTURE OF WINTER TOURISM IN PLANINA POD GOLICO IN THE LIGHTS OF GLOBAL WARMING}

\section{Summary}

Article shows temperature changes and changes in snow cover at local ski area Španov vrh near Planina pod Golico in Slovenian part of Karavanke Mountains. Climate change is the result of global warming due to increased greenhouse effect, caused by emitting carbon dioxide and other greenhouse gases, mainly from fossil fuels. This already affected winter tourism in middle and low elevations, however, even more negative impact is expected. Ski area Španov vrh has local importance and has faced many problems in last decades due to lack of investments and unpredictable snow cover conditions. Linear trends of mean daily temperature and linear trends of days with snow cover from meteorological station at Planina pod Golico (970 m a.s.1.) were analyzed and they show significant climate changes in last 30 years. Number of days with snow cover in period 1979-2008 has decreased for 18 days, but much stronger trend was recognized for days with snow cover deeper than $30 \mathrm{~cm}$ : in 30 years, the linear trend was -55 days, the fall from 77 to 22 days.

Changes in mean daily temperatures from December to March are also problematical for investing in winter tourism. Linear trend for 30 years is $+1,3{ }^{\circ} \mathrm{C}$, what exceeds global forecasts. However, trends between months are very different. In December, the temperature trend shows even slight decrease of mean daily temperature $\left(-0,3{ }^{\circ} \mathrm{C}\right.$ in 30 years), but January $\left(+2,7^{\circ} \mathrm{C}\right)$, February $\left(+2,4^{\circ} \mathrm{C}\right)$ and partly March $\left(+0,9^{\circ} \mathrm{C}\right)$ are significantly warmer.

Instead of investing in classical winter tourism infrastructure, such as new ski slopes or new chair lift, the article recommends shift towards sustainable all-season tourism which doesn't exceed the carrying capacity of mountain landscape. Because Planina pod Golico is a small village with only one ski slope and very limited possibilities for expanding ski capacities comparing to other areas in the neighbourhood, it cannot compete with larger and much more famous ski areas, such as Kranjska Gora, Vogel and Krvavec in Slovenia, Nassfeld/Mokrine (Austria) or Monte Lussari/Svete Višarje (Italy).

The village should look for a new tourism niche in connection with other small Alpine communities who decided to offer green, sustainable all-year tourism. Some of these communities are organized within networks Alpine Pearls or Alliance in the Alps, and both networks promote sustainable tourism. Such communities are Werfenweng (Austria), Chamois (Italy), Budoia (Italy), and many others.

New tourist offer should be based on:

- local ecological products such as food, wood, etc.;

- local heritage and tradition;

- building energy-efficient tourist infrastructure (apartments, small hotels), mountain hut should be renewed in first ecological mountain hut in Slovenia and would get the eco-certificate; 
- village Planina pod Golico should become first tourist village in Slovenia with sustainable transport plan for visitors and locals.

Only with new, sustainable paradigm of tourism, tourist areas will be able to compete with global warming, and small resorts, such as Planina pod Golico, can make faster and more successful shift towards sustainability, so they can compete with bigger tourist areas.

(Translated by Matej Ogrin) 